\title{
LEAF ANATOMY OF RUBBER-TREE CLONES
}

\author{
Maria Bernadete Gonçalves Martins*; Rodrigo Zieri \\ UNESP/Campus do Litoral Paulista - Unidade São Vicente - Praça Infante Dom Henrique, s/n - 11330-900 - São \\ Vicente, SP - Brasil. \\ *Corresponding author <bernadete@csv.unesp.br>
}

\begin{abstract}
Rubber trees are easily recognizable for being woody, medium to large-sized plants, having a typical deciduous behavior, and especially because they produce latex. The purpose of this work was to study the anatomy and morphology of the leaf, comparing rubber tree [Hevea brasiliensis (Willd. ex Adr. de Juss.) Muell.-Arg.] clones (RRIM 600 and GT 1) grafted on the same root stock (Tjir 1), grown under the same climatic and soil conditions. This study allowed clones to be differentiated and also provided information on the location and disposition of laticifers in the leaf tissue. Cross sections of the mesophyll, center ribbing and petiole regions were made, followed by usual permanent histological blade methods. Biometric analyses of tissue extensions in the palisade and spongy parenchymas were carried out, and the number of cells in the spongy parenchyma were counted. At the same time, biometrical analyses were made for stomata. The comparison between the clones showed that there were no significant differences in epidermal cell height, spongy parenchyma height, number of cells in the spongy parenchyma layer, and size and width of leaflets. However, variation was observed for cell thickness in the palisade parenchyma. The clone GT1 presented greater thickness as compared to the RRIM 600 clone. GT1 had also a greater number of stomata in comparison to RRIM 600, but they were smaller. GT1 presented greater petiole and center ribbing diameters in the leaves and a greater amount of sclerenchyma fibers than RRIM 600.
\end{abstract}

Key words: Hevea brasiliensis, leaf, clones

\section{ANATOMIA FOLIAR DE CLONES DE SERINGUEIRA}

\begin{abstract}
RESUMO: A seringueira é uma planta de fácil reconhecimento por ser lenhosa, de porte mediano a grande, que apresenta um padrão característico de desfolha e reenfolhamento e, sobretudo, pela produção de látex. O objetivo do trabalho foi efetuar um estudo anatômico e morfológico foliar, comparando os clones RRIM 600 e GT 1 de seringueira [Hevea brasiliensis (Wild. ex Adr. de Juss.) Muell.- Arg], desenvolvidos sob as mesmas condições edáficas e climáticas, para obtenção de informações que possam fornecer subsídios para correlações com dados fisiológicos e também diferenciar os clones em relação ao conteúdo de fibras, espessamento de tecidos do parênquima paliçádico e do parênquima lacunoso, caracterização anatômica do pecíolo, número e tamanho de estômatos e fornecer dados referentes a morfologia foliolar. Foram realizadas secções transversais na região do mesófilo, nervura central e pecíolo, seguindo-se os métodos usuais de preparação de lâminas permanentes. Foram realizadas análises biométricas de extensões de tecidos dos parênquimas paliçádico e lacunoso e contagem do número de células do parênquima lacunoso. Paralelamente foram realizadas análises biométricas para aferições de estômatos. Não houve diferenças para a altura das células epidérmicas, altura e número de camadas do parênquima lacunoso e para o comprimento e para a maior largura do limbo foliolar. Porém houve variação para a espessura das células do parênquima paliçádico, sendo que GT 1 apresentou maior espessura em relação a RRIM 600. GT1 apresentou maior número de estômatos em relação a RRIM 600, porém com menor tamanho. GT1 apresentou maior diâmetro da nervura central da folha e do pecíolo e maior quantidade de fibras de esclerênquima que RRIM 600.
\end{abstract}

Palavras-chave: Hevea brasiliensis, folha, clones

\section{INTRODUCTION}

The interest shown by the industry in using materials less harmful to the environment is making natural rubber to regain the ground taken over by synthetics in many areas, such as automotive upholstery. As an example, the European Mercedez Benz plants produce upholstery from coconut fiber and natural rubber to replace isocyanatebased polyurethane, which is highly toxic and is being prohibited throughout Europe (Schuh \& Gayer, 1997).
The rubber tree [Hevea brasiliensis (Willd. ex Adr. de Juss.) Muell.-Arg.] (Euphorbiaceae) is an easy-to-recognize species because it is woody, medium-to-large sized, and presents a typical leaf shedding and renovation pattern, with compound digitate leaves, pale yellow inflorescences, and pentamerous, hermaphrodite flowers; fruits are trilocular, barochoric; the plant characteristically yields latex. When grafted, the rubber tree plant consists of two parts a scion (upper part of the plant) and a rootstock (located at the bottom). In commercial plantings, clones are 
usually selected based on their adaptability to local conditions. With regard to the rootstock, as long as it meets ideal grafting requirements, little importance is given to it with respect to its origin or descendence. However, the influence of the rootstock on scion growth and yield has been long demonstrated; variations from 14 to $40 \%$ in yield, and from 7 to $25 \%$ in growth have been observed, and related to rootstock heterogeneity (Gonçalves et al., 1994).

Eleven rubber tree species are found in Brazil (Gonçalves et al., 1990); the country is the primary center of genetic diversity for seven of those species (Wycherley apud Colombo et al., 1989), including $H$. braziliensis, the main source of natural rubber, and the raw material utilized by several branches of the industry. Even though the rubber tree is a crop originated in a region of tropical and humid climate (Bastos \& Diniz, 1975), the commercial production regions span from $24^{\circ} \mathrm{N}$ (China) down to $25^{\circ} \mathrm{S}$ (coastal region of the State of São Paulo), indicating that it possesses an exceptional adaptability to a great variety of edaphic-climatic conditions (Ortolani, 1986). However, clones adapted to a given region do not always present the same performance in different regions, because of the interaction between genotype and environment (Gonçalves et al., 1982).

A great number of evidences or anatomical parameters have been utilized to characterize xerophytic plant individuals or populations. Anatomical parameters characterized as xerophytic were observed by means of comparative anatomical studies that utilized six different rubber tree clones to establish correlations with physiological parameters (Medri \& Lleras, 1983).

Many authors have postulated the occurrence of leaf variations under different ecological conditions. Shields (1950) and Esau (1960) verified that environmental factors can induce structural variations, causing xeromorphy. The most utilized factors to characterize xerophytism include: a great number of stomata (Salisbury, 1927) and leaf thickening with greater compaction of the mesophyll (Esau, 1960). In a comparative anatomical study using six Amazonian clones of Hevea spp in the Amazon region (Medri \& Lleras, 1983), observed a tight correlation between leaf structure and their behavior, indicating that anatomical features can be efficiently utilized as an indicator of drought tolerance, photosynthetic efficiency and, as a consequence, productivity.

The objective of this work was to conduct an anatomical and morphological study of the leaf by comparing two clones (RRIM 600 and GT 1), grafted on Tjir 1 rootstock, grown under the same edaphic and climatic conditions, aiming to obtain information that may provide support for correlations with physiological data, and to discriminate clones with regard to their fiber contents, tissue thickening in the palisade and spongy parenchymae, anatomical characterization of the petiole, number and size of stomata, as well as to provide data on leaflet morphology.

\section{MATERIAL AND METHODS}

The clone evaluation experiment was installed in January 1989 in Votuporanga-SP (20 20' S; 49 58' $\mathrm{W}$; altitude $510 \mathrm{~m}$ ), on a Typic Haplustalf with a moderate latosolic A horizon, eutrophic, and medium sandy texture. Trees were planted spaced $7.0 \mathrm{~m}$ between rows and $3.0 \mathrm{~m}$ between plants, occupying a total area of 1.2 ha, divided into three blocks of plots containing 24 trees of each clone. In addition to establishing a comparative analysis between the anatomy and morphology of the clones RRIM 600 and GT1, which are among those frequently recommended for the Planalto (Plateau) region (Gonçalves et al., 1991), a histological characterization of the leaf blade and petiole was carried out. Adult leaves were collected from 10 year-old trees, at the lower canopy layer ( $8 \mathrm{~m}$ above soil surface), in good phytosanitary shape and under shade. The middle portion of the central leaflet and of the petiole was used for analysis.

The preparation of materials to obtain histological slides for optical microscopy basically consisted of ordinary microtomy procedures, which include: fixation of plant material (FAA-50\%) with vacuum pumps, dehydration in alcoholic series (ethyl), paraffin infiltration, embedding, microtomy techniques, spreading of the sections, double-staining and mounting on permanent slides (Medri \& Lleras, 1983). The paraffinembedded specimens were sectioned with a rotary microtome, and cross sections were obtained for the leaflet blade and for the main and transversal petiole veins, to observe the cuticle, adaxial and abaxial epidermis, number of cell layers and mesophyll height, and location of laticifers, with slice thickness standardized at $10 \mathrm{~mm}$.

Jeffrey's solution (10\% chromic acid and 10\% nitric acid in equal parts) was utilized to observe the number and size of stomata; the solution received parts corresponding to the middle region of ten leaflets from each clone for dissociation of the epidermides and the parts remained in solution for approximately 72 hours. After dissociation, epidermides were stained in safranin. The two clones present higher stomatal density at the middle region of the leaflet (Coutinho \& Conforto, 2001). Determination of stomatal number and size was performed with an eyepiece grid.

The parameters utilized for morphological characterization were length and greatest width measurements of 20 middle leaflets from each clone. The clearing technique (Felipe \& Alencastro, 1966) was also utilized in this work to establish differences between venation patterns. The results were statistically analyzed using the t-Student test for comparisons between means. 


\section{RESULTS AND DISCUSSION}

Histological analyses allowed the two clones (RRIM 600 and GT1) to be studied with regard to several morphological and anatomical parameters (Tables 1 and 2) that are references for diagnosing drought resistance of plants. The leaflet blades (Figure 1) of Hevea brasiliensis are dorsiventral and present an adaxial epidermis, uniseriate palisade parenchyma, spongy parenchyma with three to four cell layers, and an abaxial epidermis. With regard to the abaxial and adaxial epidermal heights, no differences were found between clones (Table 1).

The adaxial epidermis is glabrous in both clones, as described by Medri (1977) and, optically, the abaxial epidermis has hairlike prominences, which were identified as cuticular projections by Medri \& Lleras (1984) through scanning electron microscopy.

Clones presented differences with respect to palisade parenchyma height; GT1 had a higher mean (0.49 $\mathrm{mm})$ in relation to RRIM $600(0.15 \mathrm{~mm})$, which probably suggests greater photosynthetic efficiency (Table 1). Differences were also found by Coutinho \& Conforto (2001), who recorded means of $33.88 \mu \mathrm{m}$ for RRIM 600 and $42.77 \mu \mathrm{m}$ for GT 1 . No differences were verified when values for height and number of layers in the spongy parenchyma were compared (Table 1). Coutinho $\&$ Conforto (2001) observed that this anatomical parameter was distinct in both clones; RRIM 600 had a mean of $48.07 \mu \mathrm{m}$ and GT1 of $54.79 \mu \mathrm{m}$.
The RRIM 600 clone had the greatest mean for stomatal length and width (Table 2). The mean number of stomata per unit area differed between the two clones. The GT 1 clone had greater number of stomata (Table 2). Samsuddin (1980) verified great overlapping of stomata while determining stomatal density in seven Hevea species, including four $H$. brasiliensis clones, and also observed a mean number of stomata equal to $465.09 \mathrm{~mm}^{-2}$ for RRIM 600 and $371.8 \mathrm{~mm}^{-2}$ for GT1. Gomez \& Hamzah (1980) observed differences in stomatal density between trees within the same clone, between leaf ages within the same clone (older leaves usually having a greater number of stomata), and between leaf sampling locations (proportionally greater numbers of stomata for leaves more exposed to the sun).

As observed in the present work and also described by Medri (1977), laticifers occur in the phloem region of the veins and between the palisade and spongy parenchymas of the leaflet blade (Figure 1). The morphological pattern of RRIM 600 and GT1 leaves is of leaflets elliptical in shape, apex acuminate, base concave, margin entire, slightly undulate; the primary venation pattern is pinate and the other veins $\left(2^{\text {nd }}\right.$ and $\left.3^{\text {rd }}\right)$ are reticulate (Figure 2 A-C).

Leaflet differentiation occurred at the edge region, in relation to the intramarginal space; this was observed through the clearing process. The GT1 clone has a greater and well-defined intramarginal space in relation to the RRIM 600 clone, (Figure 2 B-D). Mechanical reinforcements, represented by abundant sclerenchyma de-

Table 1 - $\mathrm{P}$ and $\mathrm{t}$ values for abaxial and adaxial epidermal heights, palisade parenchyma height, spongy parenchyma height and number of cell layers in the spongy parenchyma between rubber tree clones $(M \pm S E M)$.

\begin{tabular}{llllll}
\hline Clones & \multicolumn{1}{c}{ Ada. Epid. } & Aba. Epid. & P.P. height & S.P. height. & S.P. layers \\
\hline & - & $0.11 \pm 3.7 \times 10^{-3}$ & $0.15 \pm 12 \times 10^{-3}$ & $0.52 \pm 13 \times 10^{-3}$ & $3.60 \pm 1.12 \times 10^{-1}$ \\
RRIM 600 & $0.12 \pm 4 \times 10^{-3}$ & $0.11 \pm 4.6 \times 10^{-3}$ & $0.49 \pm 13 \times 10^{-3}$ & $0.48 \pm 22 \times 10^{-3}$ & $3.75 \pm 1.43 \times 10^{-1}$ \\
GT 1 & $0.12 \pm 4 \times 10^{-3}$ & 0.18 .68 & 1.4 & -0.82 \\
\hline T & 0.18 & 0 & $0 *$ & $0.17^{\mathrm{ns}}$ & $0.41^{\mathrm{ns}}$ \\
P & $0.86^{\mathrm{ns}}$ & $1^{\mathrm{ns}}$ & & &
\end{tabular}

*significant $(P=0.05)$

${ }^{\mathrm{ns}}$ non significant

Table 2 - $\mathrm{P}$ and $\mathrm{t}$ values for length, width and stomatal density, and central leaflet length and width between rubber tree clones $(\mathrm{M} \pm \mathrm{SEM})$.

\begin{tabular}{|c|c|c|c|c|c|}
\hline Clones & Ada. Epid. & Aba. Epid. & P.P. height & S.P. height. & S.P. layers \\
\hline & \multicolumn{2}{|c|}{ - } & $\mathrm{mm}^{2}$ & 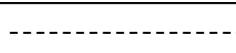 & 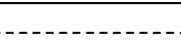 \\
\hline RRIM 600 & $0.43 \pm 11 \times 10^{-3}$ & $0.30 \pm 12 \times 10^{-3}$ & $296.25 \pm 7.88$ & $12.51 \pm 0.26$ & $5.01 \pm 0.11$ \\
\hline GT1 & $0.33 \pm 11 \times 10^{-3}$ & $0.23 \pm 10 \times 10^{-3}$ & $364.15 \pm 9.39$ & $12.52 \pm 0.35$ & $5.24 \pm 0.12$ \\
\hline $\mathrm{T}$ & 6.74 & 4.43 & -5.53 & -0.02 & -1.32 \\
\hline$P$ & $0^{*}$ & $0 *$ & $0 *$ & $0.98^{\mathrm{ns}}$ & $0.19^{\mathrm{ns}}$ \\
\hline
\end{tabular}

*significant $(P=0.05)$

${ }^{\mathrm{ns}}$ non significant 
velopment, increase with plant height (xerophytism), and are interpreted as structures that reduce the harmful effects caused by wilting (Medri, 1977). Analysis of the leaflet's central veins and of the petiole revealed that the GT1 clone has greater leaflet's midrib vein diameter and greater petiole diameter (Figures 3 and 4). The GT1 clone presented a greater amount of sclerenchyma fibers, which suggests that it is more resistant than RRIM 600 clone in withstanding drought periods, by reducing wilting.

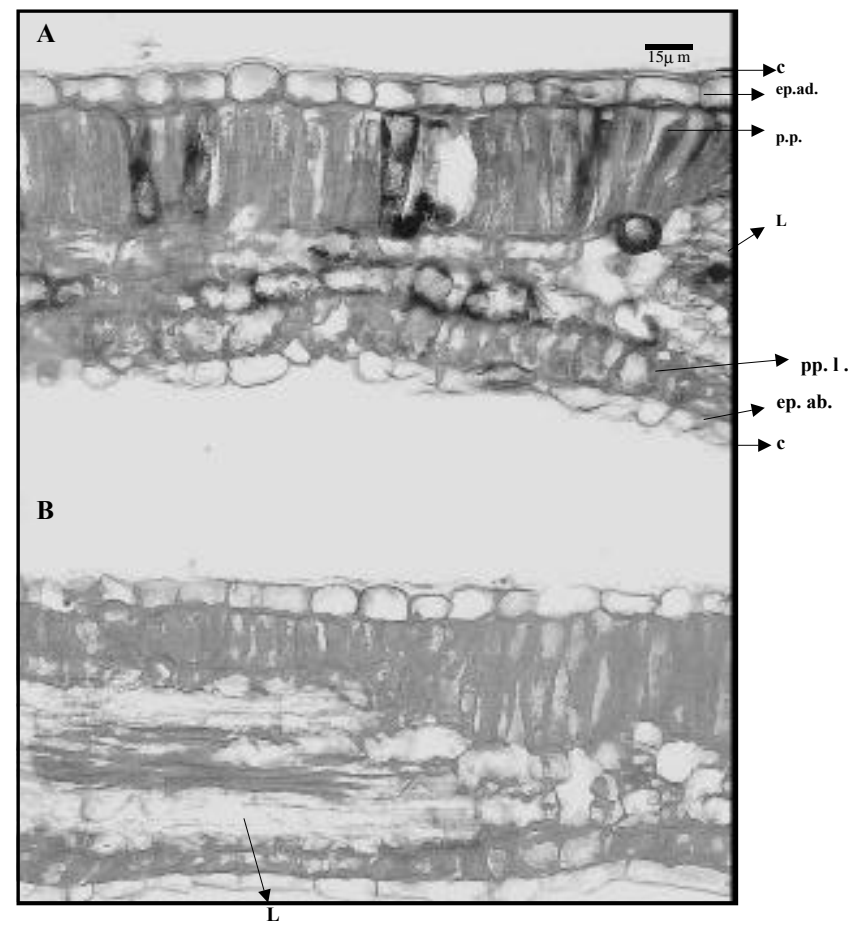

Figure 1 - Cross sections at the leaflet blade region of Hevea brasiliensis. Astra blue-safranin staining. A- RRIM 600 clone; B- GT1 clone. (c-cuticle; ep.ad.- adaxial epidermis; p.p.- palisade parenchyma; L-laticifer; p.l.spongy parenchyma; ep.ab.- abaxial epidermis).

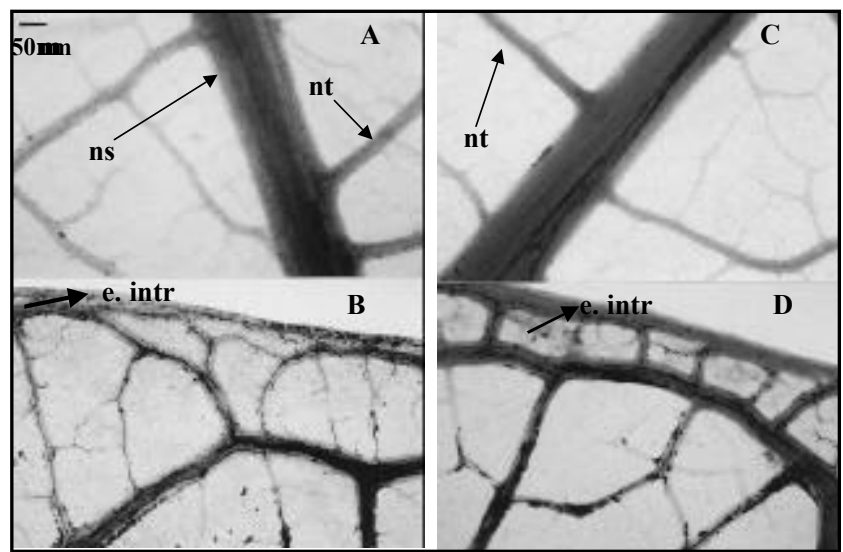

Figure 2 - Cleared leaves of Hevea brasiliensis. A: RRIM 600 clone showing secondary and terciary veins. B: RRIM 600 clone showing the edge region, near the leaf apex. C: GT1 clone showing secondary and terciary veins. D: GT1 clone showing the edge region, near the leaf apex. (ns secondary vein; nt - terciary vein; e.intr- intramarginal space)

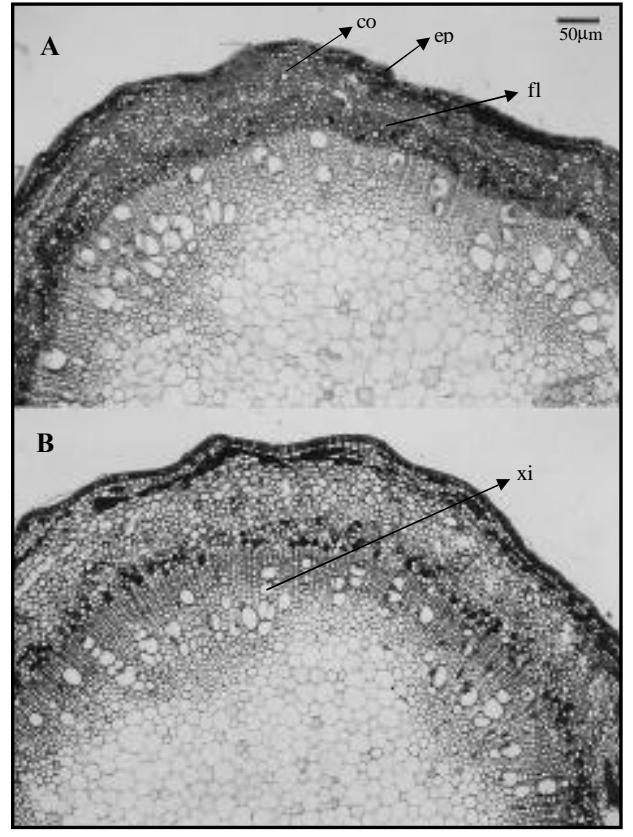

Figure 3 - Cross sections at the petiole region of Hevea brasiliensis leaves. Astra blue-safranin staining A: RRIM 600 clone B: GT1 clone $(\mathrm{co}=$ cortex; $\mathrm{ep}=$ epidermis; $\mathrm{fl}=$ phloem; $\mathrm{xi}=$ xylem).

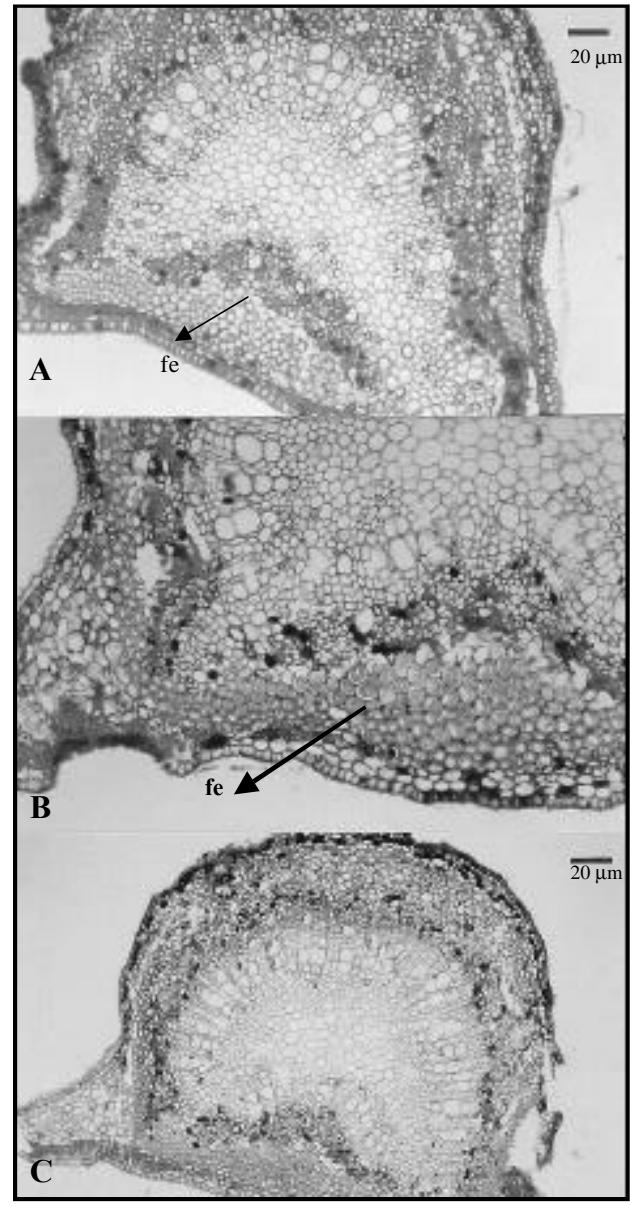

Figure 4 - Cross sections at the midrib region of Hevea brasiliensis central leaflets. Astra blue-safranin staining. A: RRIM 600 clone, B: GT1 clone, C: GT1 clone, (fe = sclerenchyma fibers). 


\section{REFERENCES}

BASTOS, T.X.; DINIZ, T.D.A.S. Clima típico da seringueira. Belém: EMBRAPA, CPATU, 1975. 12p.

COLOMBO, C.A.; GONÇALVES, P.S.; CARDOSO, M.; BOAVENTURA, M.A.M.; MARTINS, A.L.M. Importância, conservação e uso do germoplasma em Hevea spp. O Agronômico, v.41, p.21-25, 1989.

COUTINHO, A.C.F.; CONFORTO, E.C. Desenvolvimento vegetativo, estrutura do limbo foliolar e trocas gasosas em plântulas de cinco clones de seringueira (Hevea brasiliensis, Müell. Arg.) Naturalia, v.26, p.159174, 2001.

ESAU, K. Anatomy of seed plants. New York:Wiley \& Sons, 1960. 376p.

FELIPE, G.M.; ALENCASTRO, F.M.M.R. Contribuição ao estudo da nervação foliar das compostas dos cerrados. I - Tribos Helinieae, Heliantheae, Inuleae, Mutisieae e Senecioneae. Anais da Academia Brasileira de Ciências, v.38, p.125-158, 1966. Suplemento.

GOMEZ, J.B.; HAMZAH, S.B. Variations in leaf morphology and anatomy between clones of Hevea. Journal of the Research Institute of Malaysia, v.28, p.157-172, 1980.

GONÇALVES, P.S.; PAIVA, J.D.; TRINDADE, D.R.; VALOIS, A.C.C.; VIÉGAS, I.J.M. Comportamento preliminar de alguns clones de seringueira. Pesquisa Agropecuária Brasileira, v.17, p.1447-1456, 1982.

GONÇALVES, P.S.; CARDOSO, M.; ORTOLANI, A.A. Origem, variabilidade e domesticação da Hevea: uma revisão. Pesquisa Agropecuária Brasileira, v.25, p.135-156, 1990.

GONÇALVES, P.S.; MARTINS, A.L.M.; BOAVENTURA, M.A.A.; ORTOLANI, C.A. Clones de Hevea: influência dos fatores ambientais na produção e recomendação para o plantio. Boletim Técnico do Instituto Agronômico, n.138, 32p. 1991.

GONÇALVES, P.S.; MARTINS, A.L.M.; GORGULHO, E.P.; BORTOLETTO, N. BERMOND, G. Influência de seis porta-enxertos no crescimento de clones de seringueira - avaliação preliminar. Pesquisa Agropecuária Brasileira,v.29, p.553-560, 1994.
MEDRI, M.E. Alguns aspectos da anatomia de folha de Hevea brasiliensis Müell. Arg. Manaus: INPA, 1977. 107p. (Dissertação - Mestrado)

MEDRI, M.E.; LLERAS, E. Quantificação e uso de caracteres anatômicos e fisiológicos de folhas na determinação de eficiência hídrica em clones de Hevea spp. Acta Amazônica, v.13, p.261-288, 1983.

MEDRI, M.E.; LLERAS, E. Estudo comparativo do balanço hídrico em um clone diplóide ( IAN-873) e outro Poliplóide ( IAC-222) de Hevea brasiliensis MUELL. ARG. Acta Amazônica, v.14, p.128-145, 1984.

ORTOLANI, A.A. Agroclimatologia e cultivo da seringueira. In: ANAIS DO SIMPÓSIO SOBRE A CULTURA DA SERINGUEIRA NO ESTADO DE SÃO PAUlO, Campinas, 1986, Anais. Campinas: Fundação Cargill, 1986. p.11-32.

SALISBURY, E.J. On the causes and ecological significance of stomatal frequency, with special reference to woodland flora. Philosophical Transaction of the Royal Society of London. Série B, v.46, p.1-65, 1927.

SAMSUDDIN, Z. Differences in stomatal density, dimension and conductances to water vapour diffusion in seven Hevea species. Biologia Plantarum, v.22, p.154-156, 1980.

SCHUH, T.; GAYER, U. Automotive applications of natural fiber composites. Benefits for the environment and competitiveness with manmade materials. In: LEÃO, A.L.; CARVALHO. F.X.; FROLLINI, E. (Ed.) Lignocellulosic-plastics composites. São Paulo: USP, 1997. p.181195.

SHIELDS, L.M. Leaf xeromorphy as related to physiological and structural influences. Botanical Review, v.16, p.399-477, 1950.

Received October 11, 2002

Accepted August 26, 2003 